\section{Revista actual: evolución e incorporación de editores de sección}

\author{
Dr. Guillermo Ricciardi \\ Editor de sección de la Revista de la AAOT
}

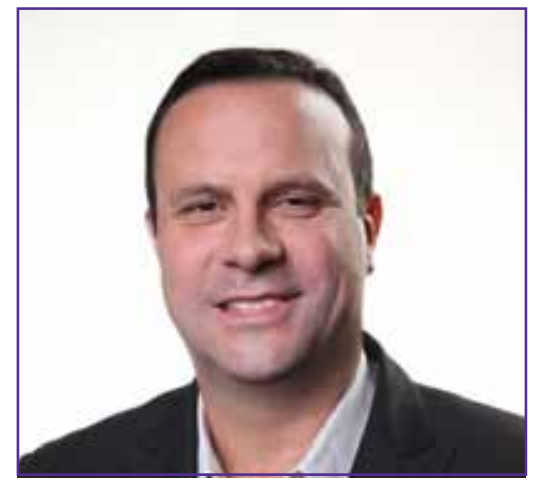

Figura 1. Dr. Juan Martín Patiño,

Editor de Sección Miembro Superior.

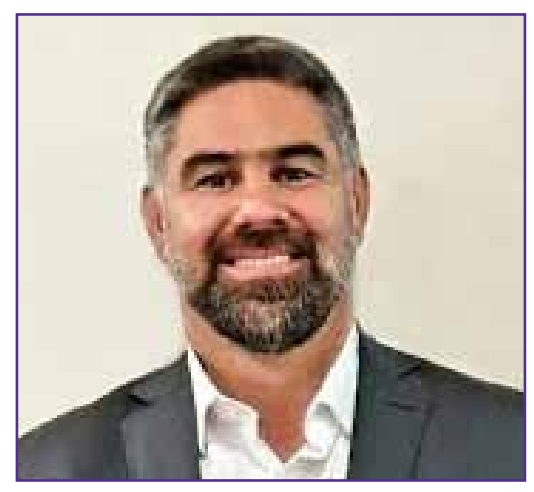

Figura 2. Dr. Gerardo Zanotti,

Editor de Sección Miembro Inferior.

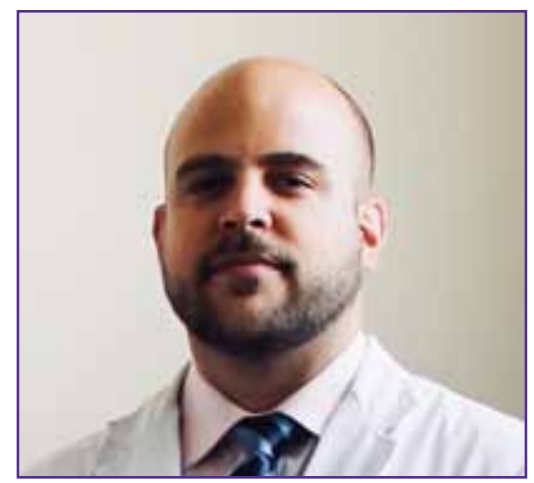

Figura 3. Dr. Guillermo Ricciardi, Editor de Sección Columna Vertebral. receptor durante el proceso editorial (Figuras 1-3).

Dr. GUILLERMO RICCIARDI • guillermoricciardi@gmail.com (ID) https://orcid.org/0000-0002-6959-9301

Cómo citar este artículo: Ricciardi G. Revista actual: evolución e incorporación de editores de sección. Rev Asoc Argent Ortop Traumatol 2021;86(2):136-137. https://doi.org/10.15417/issn.1852-7434.2021.86.2.1334 
En consecuencia, con la expansión de nuestro equipo de trabajo, el aporte constante de manuscritos y una profunda vocación científica, queremos comunicar el aumento de la frecuencia de publicación que pasará a ser bimestral con un total de 6 números por año. Inclusive algunas sociedades huéspedes participarán con contenidos científicos.

Es para nosotros una verdadera satisfacción que queremos compartir con todos los socios.

Tabla. Indizaciones de la revista de la AAOT

- ROAD (Directory of Open Access Scholarly Resources)

\section{latindex}

- Latindex (Sistema Regional de Información en Línea para Revistas Científicas de América Latina, el Caribe, España y Portugal)

- Núcleo Básico de Revistas Científicas del CAICYT-CONICET

- SciELO (Scientific Electronic Library Online)

- DOAJ (Directory of Open Access Journals)
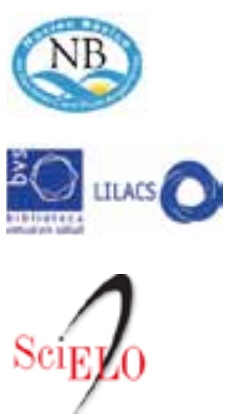

- AmeliCA

- LILACS (Literatura Latinoamericana en Ciencias de la Salud)

- Sheffield Hallam University - Library Gateway

- Catálogo de revistas científicas de la Harvard Library

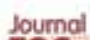

\section{- WorldCat}

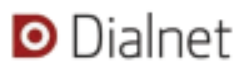

- Journal TOCs (The latest Journal Tables of Contents)

- REDIB (Red Iberoamericana de Innovación y Conocimiento Científico)
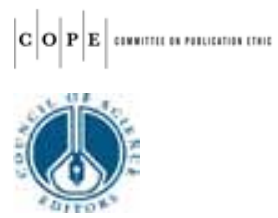

- Dialnet (Portal bibliográfico)

- Google Scholar

- BASE (Bielefeld Academic Search Engine)

- Adherida al Código de Ética del Committee of Publication Ethics (COPE) y del Council of Science Editors (CSE)

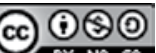

